\title{
OR9-001 - Exome sequencing in monogenic Behçet-like disease
}

\author{
Q Zhou ${ }^{1 *}$, R Laxer ${ }^{2}$, M Pelletier ${ }^{3}$, M Ramaswamy ${ }^{3}$, H-Y Wang $^{4}$, D Chin ${ }^{1}$, A Gül ${ }^{5}$, C Sibley ${ }^{6}$, M Barat-Houari ${ }^{7}$, R Siegel ${ }^{3}$, \\ DL Kastner ${ }^{1}$, I Aksentijevich ${ }^{1}$
}

From 7th Congress of International Society of Systemic Auto-Inflammatory Diseases (ISSAID) Lausanne, Switerland. 22-26 May 2013

\section{Introduction}

A Caucasian family with an affected mother and 2 affected daughters presented with early onset Behçetlike disease, manifesting with arthralgia/arthritis, mouth and genital ulcers, and uveitis. They are negative for $H L A * \mathrm{~B} 51$. Their symptoms are significantly ameliorated with TNF-inhibitors.

\section{Objectives}

To identify the causative mutation(s) in this family we sequenced the exomes of the 3 affected patients.

\section{Methods}

Exome data were filtered for novel variants not present in dbSNP, the 1000 Genomes Pilot Project, NHLBI Exome Sequencing Project (ESP5400), and 124 exomes from in-house data.

\section{Results}

We identified 21 putative candidate variants that are both novel and consistent with dominant inheritance. Sanger sequencing validated all 21 variants. Three variants identified in TNFRSF9, MGEA5, and TNFAIP3 genes were confirmed to have arisen de novo in the affected mother based on the genotyping of the healthy maternal grandmother, the maternal unaffected brother, and the unaffected paternal aunt. The candidate variant in MGEA5 was predicted as benign by PolyPhen-2. The 2 candidate variants that remained for consideration are p.C78W (TNFRSF9; CD137; 4-1BB) and p.L227X (TNFAIP3;A20). Haplotype analysis showed that p.C78W occurred de novo on the haplotype inherited from the grandmother. The p.L227X mutation-associated haplotype was found on the

${ }^{1}$ Inflammatory Disease Section, National Human Genome Research Institute (NHGRI/NIH), Bethesda, USA

Full list of author information is available at the end of the article grandfather's haplotype; his sample is not available for analysis. Because we reached the limit for further analysis of candidate variants in the family, we studied 6 Turkish familial Behçet cases and 56 sporadic Caucasian cases. All of these individuals were negative for mutations in either candidate gene. Both 4-1BB and A20 are strong candidates and potentially in the same signaling pathway. $4-1 \mathrm{BB}$ is a TNF-family receptor that costimulates $T$ cell responses and promotes survival of lymphocytes and dendritic cells; A20 is a negative regulator of NF-kB activation by TNF and TLR family receptors. Mutant 4-1BB expressed in Jurkat cells was associated with reduced expression on the plasma membrane, and activated $\mathrm{T}$ cells from all 3 patients had a marked decrease in surface expression, especially in $\mathrm{CD}^{+} \mathrm{T}$ cells. Despite reduced surface expression, the C78W TNFRSF9 mutation could have a gain-offunction phenotype like TNFR1 mutations in TRAPS, leading to intracellular retention of mutant protein and spontaneous signaling, which in this case could amplify immune responses by $\mathrm{T}$ cells and other cell types expressing 4-1BB. Patient peripheral blood cells also had lower total A20 protein levels relative to controls and, consistent with A20 lack of function, increased I- $\kappa$ B degradation after cellular activation.

\section{Conclusion}

Behçet-like disease in this family is associated with mutations in 2 genes that affect immune cell survival and production of inflammatory cytokines. Additional functional studies will determine whether 1 or both mutations may contribute to this dominantly-inherited phenotype.

\section{Competing interests}

None declared. 


\section{Authors' details}

'Inflammatory Disease Section, National Human Genome Research Institute (NHGRI/NIH), Bethesda, USA. ${ }^{2}$ Hospital for Sick Children, Toronto, Canada. ${ }^{3}$ Immunoregulation Section, National Institute of Arthritis and

Musculoskeletal and Skin (NIAMS/NIH), USA. "Laboratory of Host Defenses, National Institute of Allergy and Infectious Diseases (NIAID/NIH), Bethesda, USA, ${ }^{5}$ Istanbul Faculty of Medicine, Istanbul University, Istanbul, Turkey.

${ }^{6}$ Office of Clinical Director, National Institute of Arthritis and Musculoskeletal and Skin (NIAMS/NIH), Bethesda, USA. 'Département de Génétique, LBM

-CHU de Montpellier, Montpellier, France.

Published: 8 November 2013

doi:10.1186/1546-0096-11-S1-A184

Cite this article as: Zhou et al:: OR9-001 - Exome sequencing in

monogenic Behçet-like disease. Pediatric Rheumatology 2013 11(Suppl 1): A184.

\section{Submit your next manuscript to BioMed Central} and take full advantage of:

- Convenient online submission

- Thorough peer review

- No space constraints or color figure charges

- Immediate publication on acceptance

- Inclusion in PubMed, CAS, Scopus and Google Scholar

- Research which is freely available for redistribution

Submit your manuscript at www.biomedcentral.com/submit 